\title{
8. ALTERNATIVE DIAGENETIC MODELS FOR CRETACEOUS TALUS DEPOSITS, DEEP SEA DRILLING PROJECT SITE 536, GULF OF MEXICO'
}

\author{
R. B. Halley, U.S. Geological Survey, Denver, Colorado \\ B. J. Pierson, Koninklijke/Shell Expl. en Prod. Laboratorium, Rijswijk, Holland \\ and \\ Wolfgang Schlager, University of Miami, Miami, Florida
}

\begin{abstract}
Talus deposits recovered from Site 536 show evidence of aragonite dissolution, secondary porosity development, and calcite cementation. Although freshwater diagenesis could account for the petrographic features of the altered talus deposits, it does not uniquely account for isotopic or trace-element characteristics. Also, the hydrologic setting required for freshwater alteration is not easily demonstrated for the Campeche Bank. A mixing-zone model does not account for the available trace-element data, but does require somewhat less drastic assumptions about the size of the freshwater lens. Although a seawater (bottom-water) alteration model requires no hydrologic difficulties, unusual circumstances are required to account for the geochemical characteristics of the talus deposits using this model.
\end{abstract}

\section{INTRODUCTION}

The shallow-water carbonates at Site 536 (Fig. 1) are Cretaceous skeletal limestones (Unit III) that are interpreted as talus deposits. A wedge-shaped sequence seen on seismic profiles along the base of the escarpment is interpreted as the seismic image of the talus deposit (Fig. 2; Schlager, Buffler, et al., 1984). The deposits contain abundant rudists and other neritic biota and were recovered as drilling cobbles as much as $5 \mathrm{~cm}$ in diameter and core pieces as much as $13 \mathrm{~cm}$ long (Fig. 3). These rocks are interpreted as deep-water talus deposits because: (1) several layers of pelagic chalk with globigerinids and radiolarians intercalated between the shallow-water limestones were found; (2) these pelagic layers become younger upward from late Aptian at the base of the interval to late Albian at the top; and (3) clasts of pelagic chalk and tests of globigerinids are scattered throughout the shallow-water debris. Hole 536 is at a paleodepth of about $1700 \mathrm{~m}$ and is about $5 \mathrm{~km}$ east of the Campeche Escarpment, which, according to seismic stratigraphy and dredge hauls (Bryant et al., 1969), represents the Cretaceous platform margin.

The lithology, age, and setting of the limestones at Site 536 resemble those of the Tamabra Limestone at the foot of the Golden Lane platform in northern Mexico (Enos, 1977b). The two formations also share the somewhat problematic occurrence of skeletal molds, indicating selective leaching of aragonite. It is unclear, at present, if the leaching was caused by undersaturated deep water, by freshwater flow from an aquifer of the platform, or by some mixture of meteoric water and seawater. Comparable talus deposits also seem to occur in the Reforma fields west of the Campeche Bank (Meyerhoff, 1980; Viniegra, 1981). It seems that talus at the

\footnotetext{
${ }^{1}$ Buffler, R. T., Schlager, W., et al., Init. Repts. DSDP, 77: Washington (U.S. Govt. Printing Office).
}

foot of the high-rising mid-Cretaceous platforms is widespread and may well be found in similar settings, for instance, off Belize, off western Florida, and off the buried platforms along the East Coast of the United States.

\section{PETROGRAPHICAL, GEOCHEMICAL, AND PETROPHYSICAL DATA}

Thin-section analyses of Site 536 talus deposits indicate they consist primarily of mollusk and codiacean algal gravel and sand and were originally aragonite-rich (Fig. 4). These talus deposits appear to have been altered in situ; they were not altered on the shelf and transported downslope. Evidence for in situ diagenesis is threefold. First, delicate micrite envelopes and cement rims are not broken or displaced as might be expected, at least occasionally, if the material had been transported. Second, secondary pore space is never infilled by finegrained, pelagic sediment that is interlayered with the shallow-water debris whereas this pelagic sediment is occasionally found in primary intraskeletal pores. Third, aragonitic components (pteropods and ammonites) within interbedded pelagic sediments have undergone aragonite dissolution and calcite crystal precipitation identical to that in the transported shelf sediments (Fig. 5).

Porosity and permeability of these rocks are high. Less than $5 \%$ of the drilled section was recovered, and the extremely highly porous and friable nature of this unit is thought to account, in part, for poor recovery. Shipboard porosity determinations were $38,17,15$, and $27 \%$. Land-based laboratory measurements of porosity and permeability are listed in Table 1 . It is possible that sampling difficulties biased data toward the low range of porosity and permeability values. That is, coring will tend to recover more well-cemented, less porous samples. Average porosity of both shipboard and lab measurements is about $28 \%$.

Trace-element analyses are presented in Table 2 for whole rock samples of the intervals indicated. Of significance is the relatively high manganese concentration 


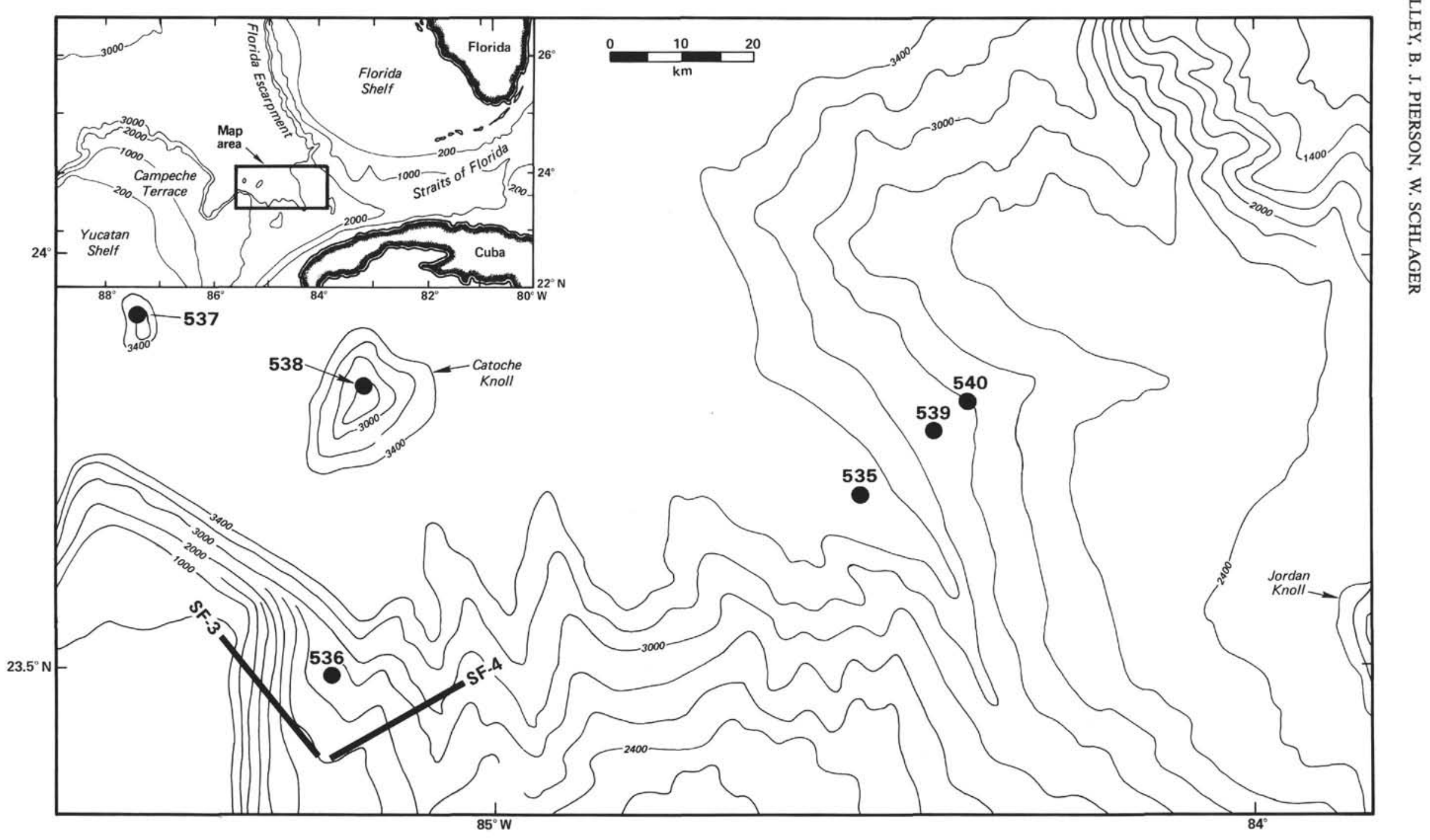

Figure 1. Location map of Site 536 in the southeastern Gulf of Mexico, along with seismic lines. 


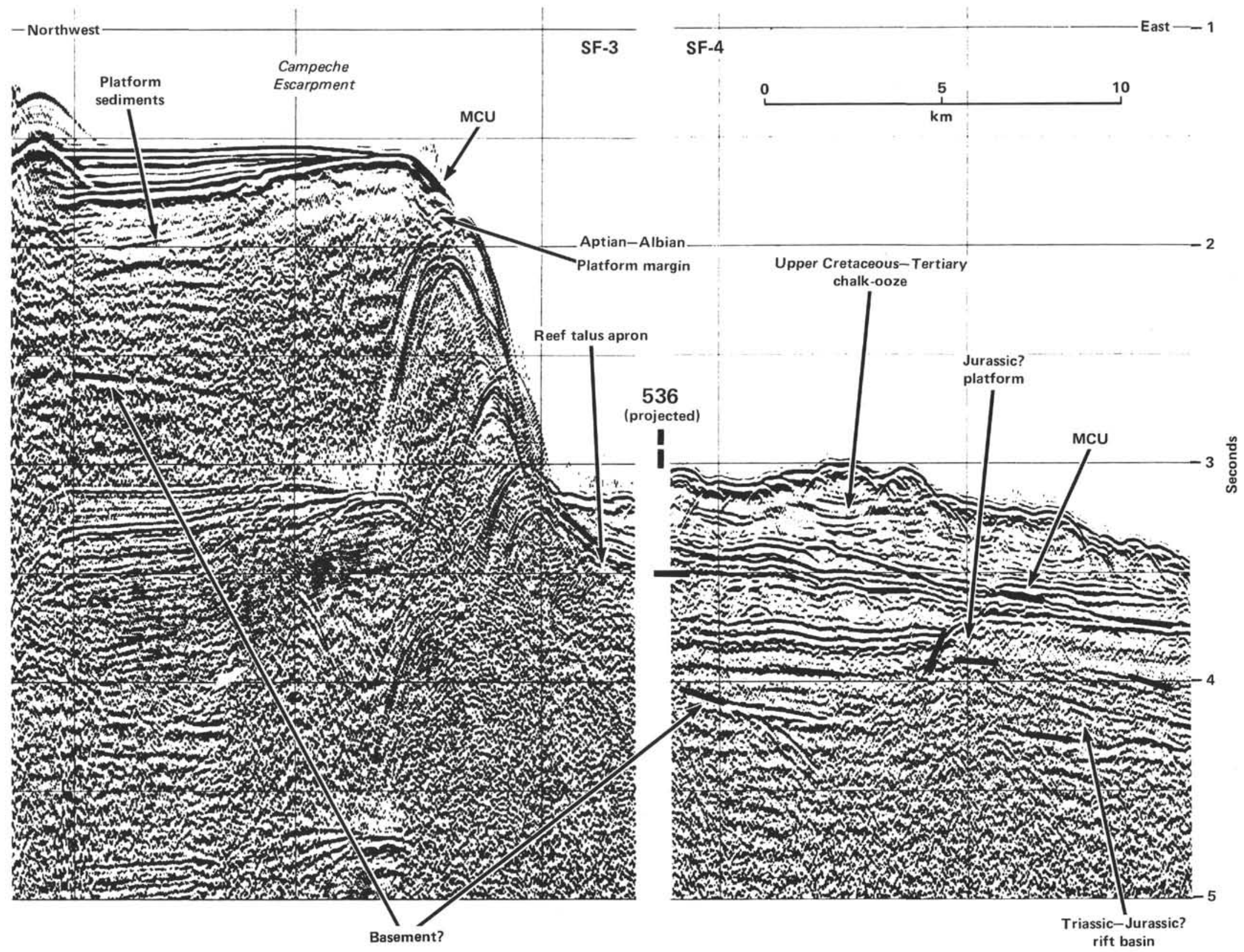

Figure 2. Seismic image of talus deposit and surrounding units. Site 536 is projected from approximately $10 \mathrm{~km}$ north of the seismic lines. MCU $=$ mid-Cretaceous unconformity. 
A

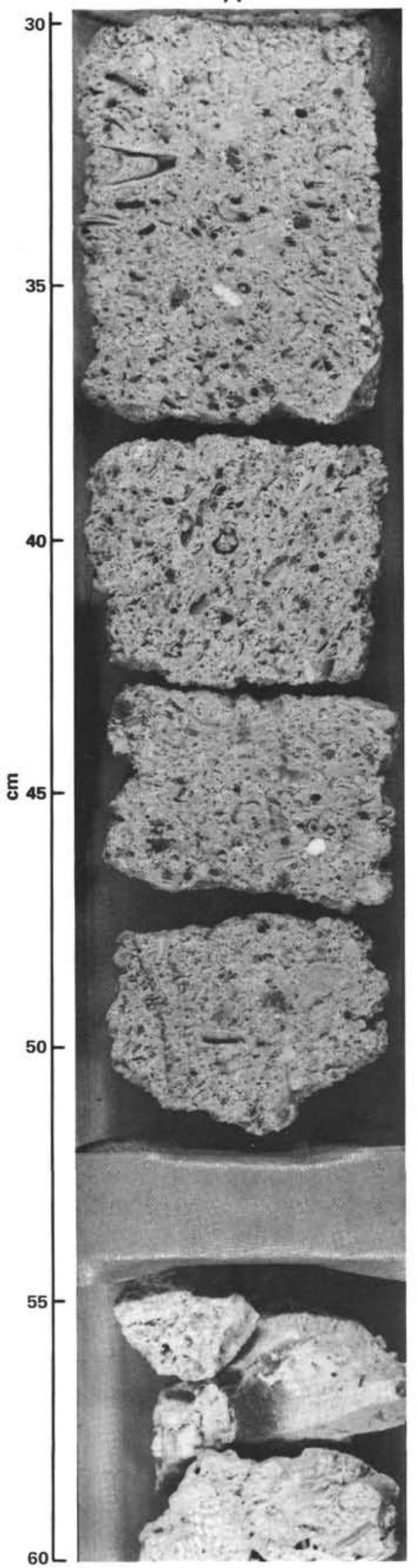

B

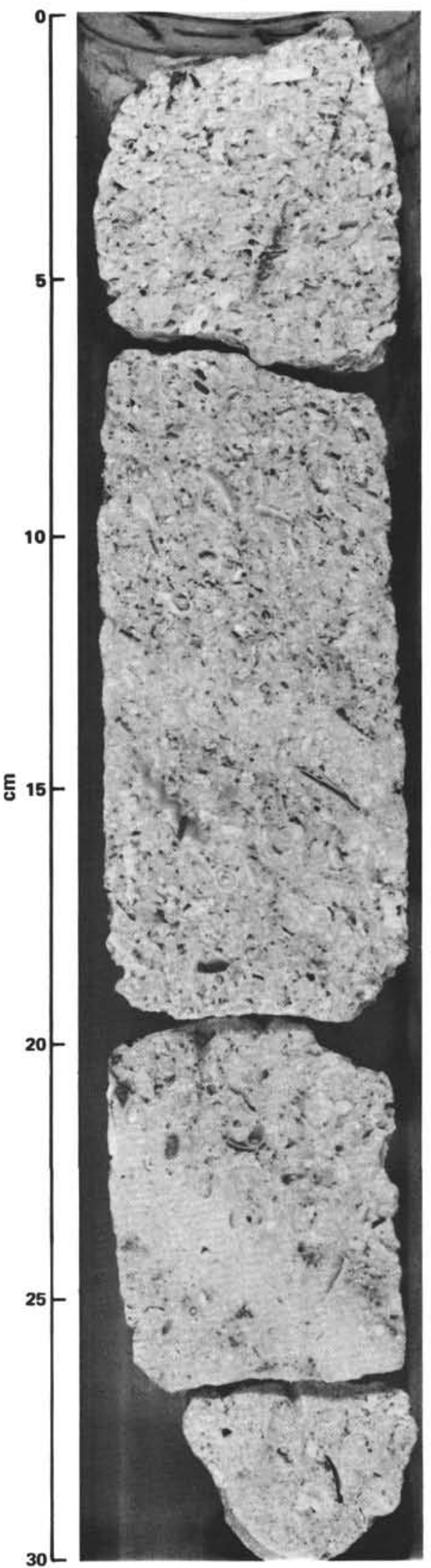

Figure 3. Short core sections and cobbles of coarse skeletal grainstones and gravels of the talus deposits cored at Site 536 . Note the poor sorting, crude bedding, and secondary porosity evident in the samples. A. Sample 536-10-1, 30-60 cm. B. Sample 536-14-1, 0-30 cm. 


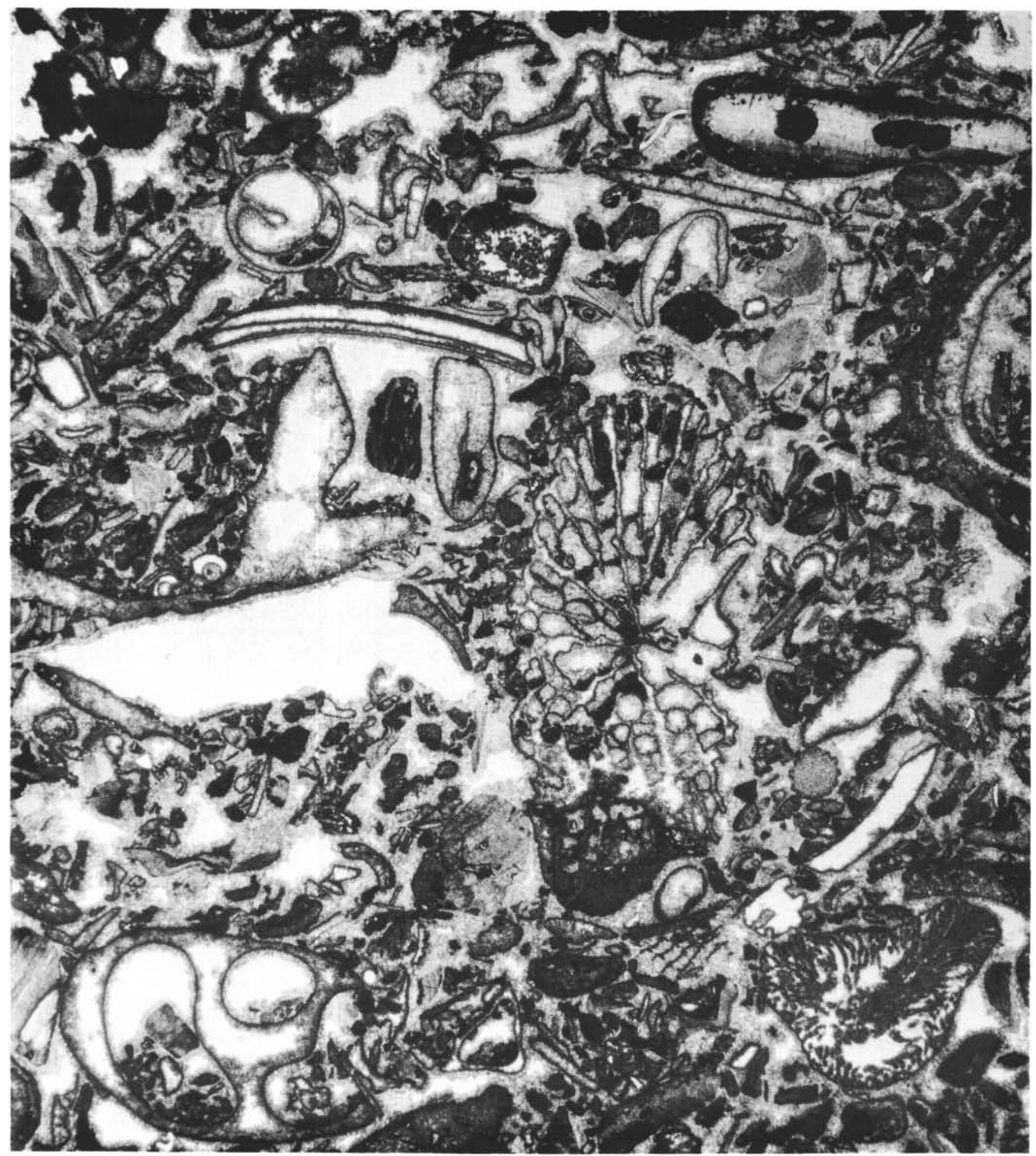

Figure 4. Photomicrograph $(27 \times 46 \mathrm{~mm})$ illustrating cemented coarse-grained, mollusk, algal grainstone with minor amounts of echinoderm, and coral debris. Sediment is typical of talus from Site 536.

and low magnesium content in grainstones. Cathodoluminescent petrography shows that manganese-rich zones exist in the calcite cements (Fig. 6).

Isotopic analyses of Site 536 shallow-water carbonates are summarized in Table 3. In Figure 7 the analyses are compared with isotopic compositions of other shal- low- and deep-water carbonate sediments. These data are discussed in the following section.

\section{DISCUSSION}

Although many of the petrographic and geochemical characteristics of this unit are typical of diagenesis in 


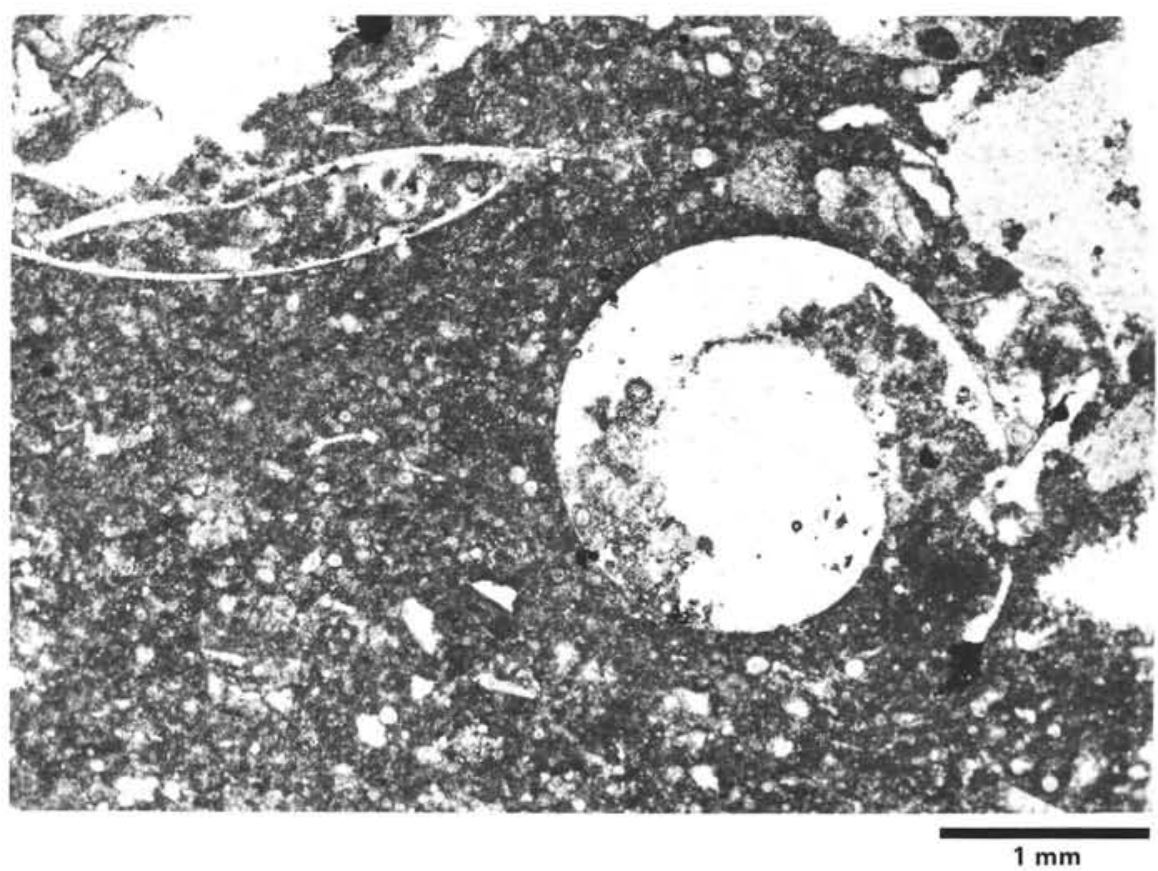

Figure 5. Photomicrograph of leached pteropod or juvenile ammonite in pelagic sediment interbedded with talus of Site 536 .

Table 1. Porosity and permeability of samples from Unit III, Hole 536.

\begin{tabular}{lcc}
\hline $\begin{array}{c}\text { Core-Section } \\
\text { (interval in cm) }\end{array}$ & $\begin{array}{c}\text { Porosity } \\
\text { (\% bulk } \\
\text { volume) }\end{array}$ & $\begin{array}{c}\text { Permeability } \\
\text { (mD) }\end{array}$ \\
\hline $10-1,5-8$ & 37 & 502 \\
$14-1,40-43$ & 35 & 483 \\
$14-1,45-49$ & 23 & 381 \\
$16-1,56-57$ & 26 & 185 \\
$18-1,22-23$ & 42 & 1552 \\
$18-1,17-21$ & 21 & 318 \\
$19-1,41-44$ & 19 & 86 \\
$20-1,24-26$ & 33 & 167 \\
\hline
\end{tabular}

Table 2. Trace element composition of samples from the Cretaceous interval of DSDP Hole 536.

\begin{tabular}{|c|c|c|c|c|c|c|c|}
\hline $\begin{array}{l}\text { Core-Section } \\
\text { (interval in } \mathrm{cm} \text { ) }\end{array}$ & $\begin{array}{l}\text { Rock } \\
\text { type }\end{array}$ & $\underset{(p p m)}{\mathrm{Na}}$ & $\underset{(p p m)}{\mathrm{Mn}}$ & $\begin{array}{c}\mathrm{Mg} \\
\text { (ppm) }\end{array}$ & $\begin{array}{c}\mathrm{Sr} \\
\text { (ppm) }\end{array}$ & $\underset{(p p m)}{\mathrm{Fe}}$ & $\begin{array}{c}\mathrm{Ca} \\
(w t . \%)\end{array}$ \\
\hline $14-1,45-49$ & $\begin{array}{l}\text { Grainstone (particles } \\
\text { and cement) }\end{array}$ & 415 & 740 & 2980 & 387 & 91 & 37 \\
\hline $14-1,46$ & $\begin{array}{l}\text { Grainstone (particles } \\
\text { and cement) }\end{array}$ & 238 & 790 & 2990 & 472 & 90 & 37.2 \\
\hline $19-1,17-21$ & Pelagic limestone & 1197 & 92 & 4200 & 1400 & 721 & 36.1 \\
\hline $14-1,45-49$ & Grainstone & 434 & 760 & 2970 & 421 & 90 & 35.8 \\
\hline $19-1,41-44$ & Pelagic limestone & 423 & 93 & 4440 & 797 & 73 & 36 \\
\hline $14-1,46$ & Grainstone & 239 & 790 & 2970 & 455 & 89 & 35 \\
\hline $19-1,17-21$ & Pelagic limestone & 1289 & 156 & 4090 & 1321 & 664 & 35.6 \\
\hline $14-1,45-49$ & Grainstone & 450 & 720 & 2970 & 375 & 105 & 37.9 \\
\hline $19-1,41-44$ & Pelagic limestone & 435 & 64 & 4050 & 620 & 205 & 36.7 \\
\hline
\end{tabular}

Note: Duplicate samples were run as cross checks on analytical procedure.

shallow-water environments, some characteristics that were once thought to be diagnostic of shallow-water diagenesis are now realized to occur also in much deeperwater environments. For example, micrite rims that were once thought to form exclusively in the photic zone now are known to develop in abyssal depths (Golubic et al., 1975). Similarly, aragonite dissolution and calcite precipitation, so common during early, freshwater altera- tion, are now known to occur at considerable depth in seawater (Schlager and James, 1978), at depths comparable to those envisioned for Unit III. Therefore, these characteristics of the talus deposits can be interpreted by several models.

The processes resulting in alteration of Aptian-Albian calcarenites at Site 536 cannot be defined by the available data. Rather, a number of alternatives are possible, some of which appear more or less reasonable. These are: (1) alteration in seawater, (2) alteration by fresh (meteoric) water, and (3) alteration by some mixture of meteoric water and seawater.

\section{Seawater Alteration}

Schlager and James (1978) documented the mineralogical stabilization of fine-grained mixtures of pelagic and bank-derived material at the deep seafloor in the Tongue of the Ocean, Bahamas. Many of the features characteristic of these Bahamian sediments also occur in the more coarse-grained deposits of Unit III. These features include: (1) aragonite dissolution and replacement by calcite; (2) calcite cement precipitation; (3) loss of magnesium from magnesium calcite; and (4) $\delta^{13} \mathrm{C}$ content. There are also several significant differences between Bahamian deep-water carbonates and Unit III rocks; in particular the $\delta^{18} \mathrm{O}$ and magnesium contents of the Bahamian sediments are considerably higher. The isotopic difference might be explained if the Cretaceous sediments were altered in water warmer than that in the Tongue of the Ocean and if less or no glacial ice were present during the alteration of the Cretaceous sediments. Both are likely assumptions in view of the evidence for more equable mid-Cretaceous climate and reduced ocean temperature gradient (Berger, 1979; Douglas and Savin, 1975). The difference in magnesium content 


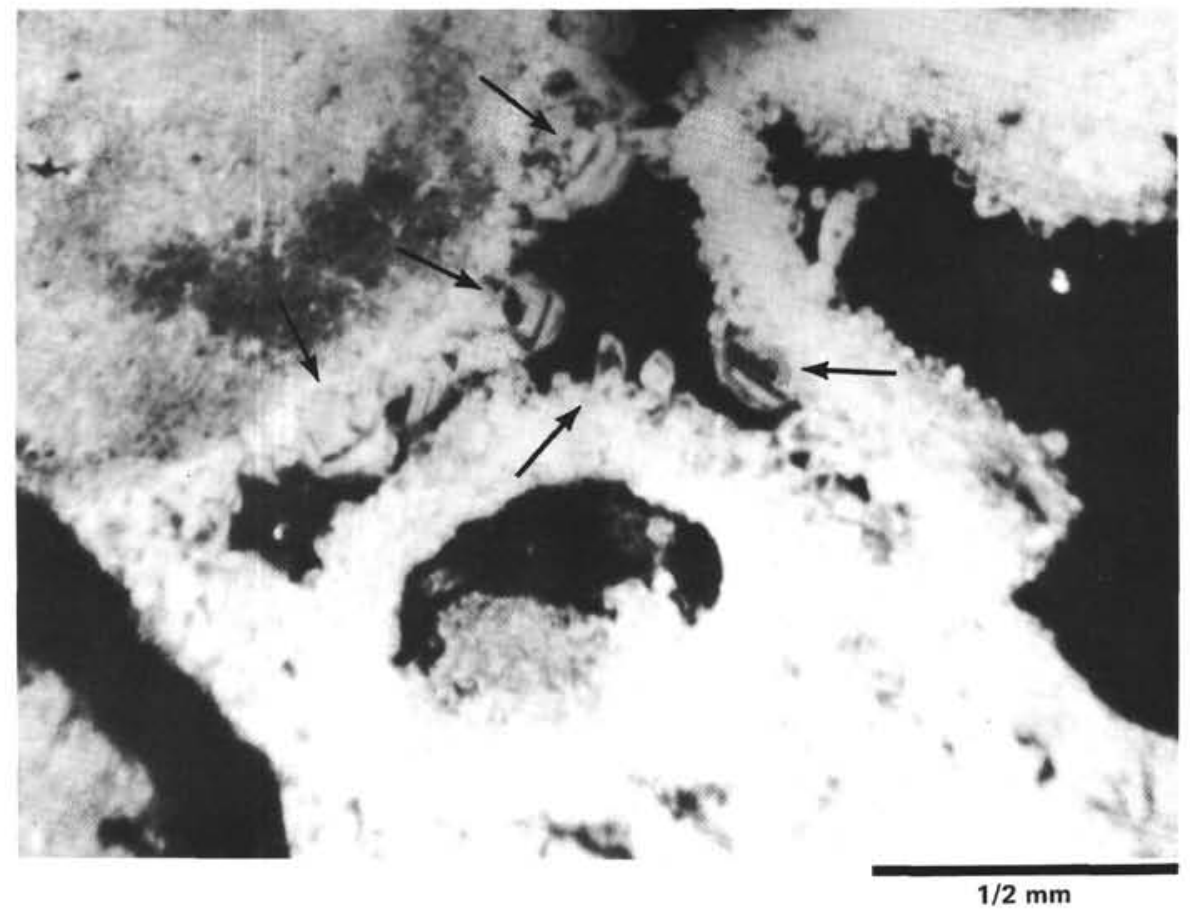

Figure 6. Luminescent light photomicrograph of larger cements exhibiting several zones of luminescent and nonluminescent calcite (arrows). Sample 536-14-1, 56-58 cm.

Table 3. Carbon-oxygen isotope analyses, Hole 536.

\begin{tabular}{ccc}
\hline $\begin{array}{c}\text { Core or } \\
\text { Core-Section }\end{array}$ & $\delta^{13} \mathrm{C}(\mathrm{PDB})$ & $\delta^{18} \mathrm{O}(\mathrm{PDB})$ \\
\hline 11 & +2.96 & -1.34 \\
14 & +2.50 & -1.13 \\
$18-1$ & +2.27 & -1.78 \\
$18-2$ & +2.49 & -0.78 \\
19 & +2.02 & -1.02 \\
20 & +2.05 & -0.57 \\
\hline
\end{tabular}

Note: Analyses by Lab voor Algemene Natuurkunde, Univ. Groningen, Netherlands.

between the Pleistocene and Cretaceous limestones is more difficult to explain. Diagenesis in warmer seawater would have probably left higher magnesium contents in the Cretaceous carbonates. The low magnesium content of Site 536 grainstones seems best explained by alteration in water with a low magnesium concentration.

Application of the model of modern seafloor dissolution and cementation to the Cretaceous is not straightforward because of fundamental differences between modern and Cretaceous oceans. However, the reduced temperature gradient of the Cretaceous ocean is significant. Deep waters were considerably warmer and consequently (other parameters being equal) more saturated with respect to carbonate. In this situation the burden of dissolving the excess carbonate fixed by plankton in the surface waters may well have shifted from the bottom waters to the midwater oxygen-minimum zone. Production of carbon dioxide from oxidation of organic matter creates a minimum of carbonate saturation in this zone, even in modern oceans (Skirrow, 1975, p. 95). Reduced dissolution in bottom waters along with higher levels of carbon dioxide in the atmosphere and surface waters (Arthur, 1982) may have considerably strengthened this saturation minimum during the mid-Cretaceous. Thus, leaching of aragonite and precipitation of calcite in the Campeche talus may have been caused by carbonate-undersaturated seawater of the oxygen-minimum layer.

Another characteristic of the Cretaceous ocean seems to be short-term fluctuations of oxygen and carbonate dissolution levels, recorded as alternation of bioturbated, carbonate-rich and laminated, carbonate-poor sediment (Berger, 1979). These fluctuations were also observed in the Gulf of Mexico and may explain the frequent zoning in cement crystals at Site 536, particularly since the zoning involves variations of the (highly redoxdependent) manganese content of the calcite crystals.

\section{Freshwater Alteration}

The petrographic characteristics of Unit III share many similarities with shallow-water, carbonate sediments that have been altered in freshwater. These similarities include (1) formation of micrite envelopes; (2) dissolution of aragonite and the development of moldic porosity; (3) replacement of aragonite by calcite; (4) precipitation of low-magnesium calcite as fringing cements; and (5) stabilization of high-magnesium calcite. These features are illustrated in Figures 8 and 9. The petrographic features of Unit III grainstones are similar to those described by Friedman (1964) and Land (1967) from shallow marine carbonates altered in meteoric ground water. The oxygen and carbon isotope ratios are less negative 


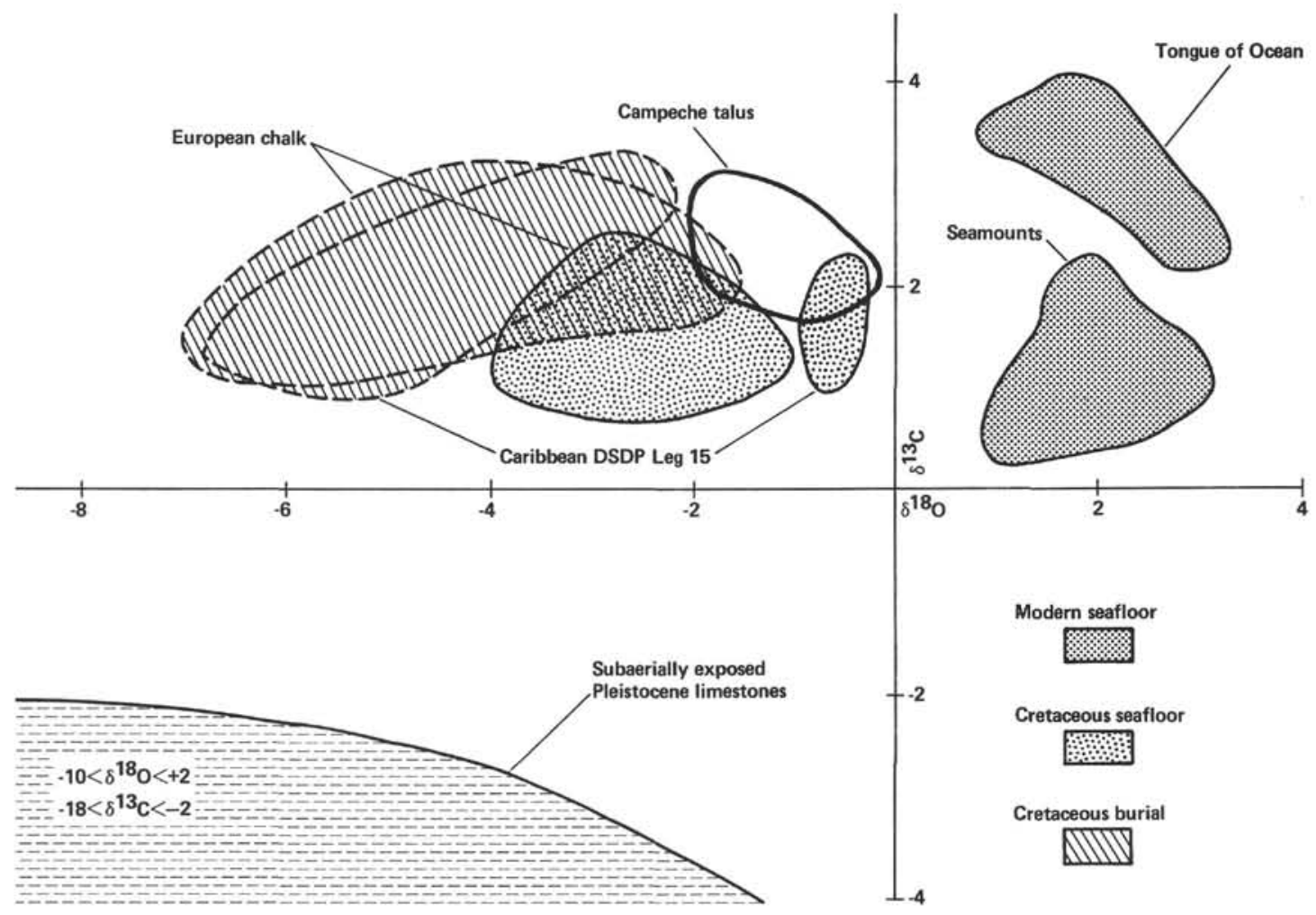

Figure 7. Cross-plot of carbon and oxygen isotope ratios for Site 536 talus deposits compared with hardgrounds, other deep-sea rocks, and sediments and Pleistocene limestones of Bermuda and the Bahamas.

than might be expected for carbonates altered in freshwater. However, Allen and Matthews (1977) have explained that carbon isotopic ratios are conserved during freshwater diagenesis of marine carbonates. Only the upper portions of a unit may be affected by bacterially fractionated light carbon. Little change from marine values of carbon isotope ratios is to be expected. Calcites are much more sensitive to the $\delta^{18} \mathrm{O}$ ratio in ground water, but this too may not be much different than $\delta^{18} \mathrm{O}$ content in marine calcite depending on the previous evaporation history of the ground water (Lloyd, 1964) and the amount of fractionation during precipitation that may be small along low-latitude coasts.

Enos (1977a) invoked meteoric water as the diagenetic medium for alteration of slope carbonates of the Tamabra Limestone, Mexico. The model requires a substantial sea-level fall and an aquiclude overlying the slope sediments so that sufficient hydrologic potential is developed in the aquifer to drive meteoric water deep below sea level and into talus deposits. If the aquifer followed a simple Gheyben-Hertzberg principle, it would require approximately $40-45 \mathrm{~m}$ of freshwater above sea level to drive the base of the aquifer as deep as these talus deposits (about $1700 \mathrm{~m}$ ). Eustatic sea-level falls of tens to hundreds of meters occurred repeatedly throughout the mid and Late Cretaceous (Hancock and Kauffman, 1979; Vail et al., 1977, fig. 6). In support of this model are the observations by Manheim (1967) of fresh and brackish water flowing from partially confined aquifers beneath the Florida Shelf.

In the absence of a well-developed aquiclude, it is impossible to develop a thick freshwater aquifer. An exam- ple is the northern Yucatan Peninsula today, which, despite having high rainfall and large areal extent, possesses a freshwater lens less than $100 \mathrm{~m}$ deep (Back and Hanshaw, 1970). Although the petrography of Unit III is most easily explained by invoking freshwater alteration, the hydrology required by this model is not easily demonstrated.

Figure 10 shows a possible scenario of a perched freshwater lens in the platform, sealed on the seaward side by a cover of fine-grained slope sediments and extensively cemented reef rims. In this model it is assumed that the interior of the carbonate platform is sealed on its seaward side by a combination of heavily cemented margin facies and fine-grained, pelagic sediments with hardgrounds. In this setting, a sea-level drop of only $45 \mathrm{~m}$ would be sufficient to create a perched freshwater lens with a hydraulic head sufficient to drive discharge at the toe-of-slope in $1200 \mathrm{~m}$ of water depth. Discharge of fresh water has been observed at $500 \mathrm{~m}$ water depth along the United States Atlantic margin (Manheim, 1967). In the case of this lens, discharge is assumed to take place where the fine-sediment cover has been eroded to expose the talus. It is doubtful that an effective aquiclude could develop on the seaward side of the platform, and, therefore, this scenario seems rather improbable.

\section{Mixing-Zone Alteration}

The interface between a freshwater aquifer and seawater is a zone of mixing in which a great variety of diagenetic processes may take place (Runnels, 1969; Plummer, 1975). The mixing zone often may be a broad interface with vertical dimensions much in excess of the fresh- 

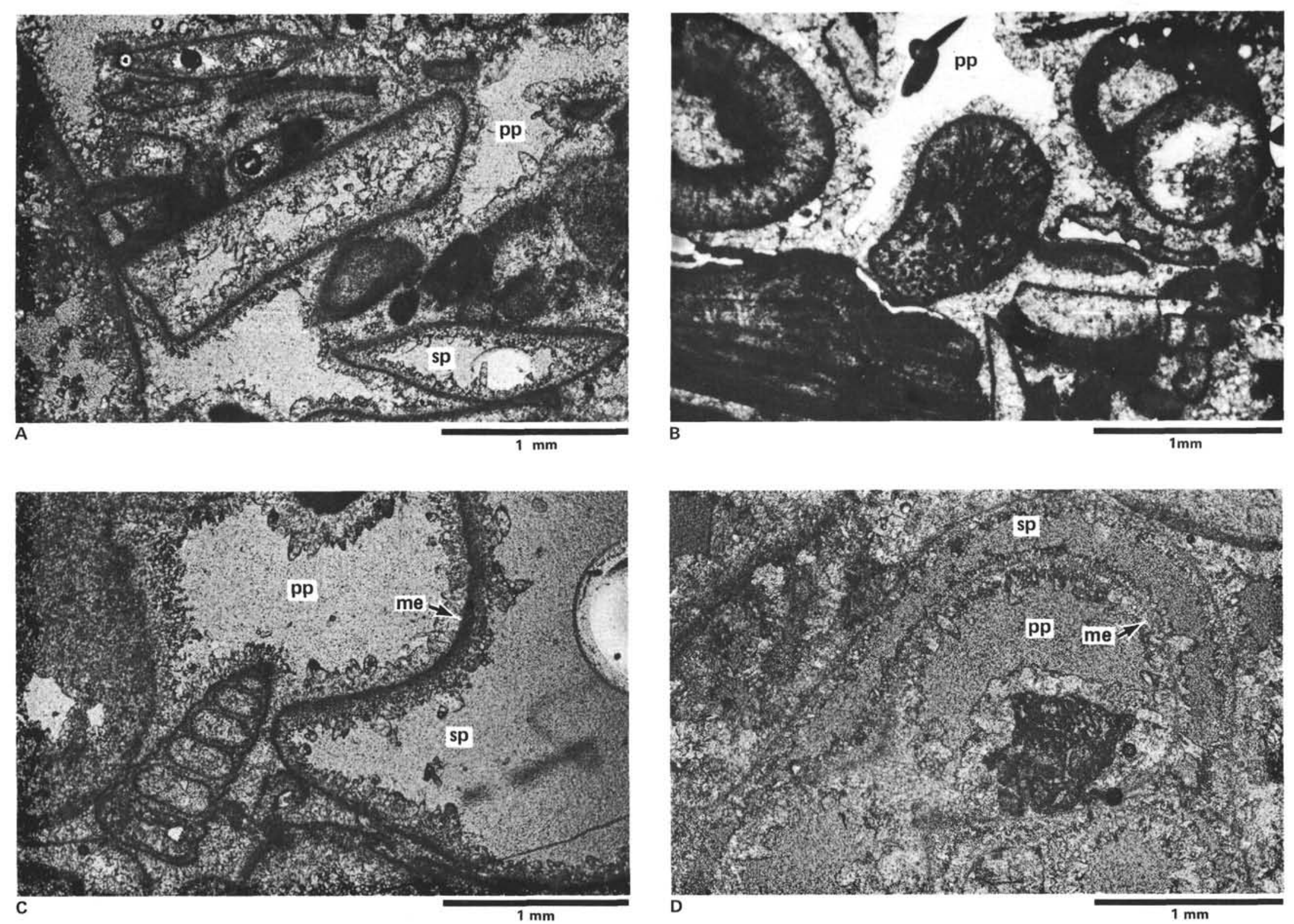

Figure 8. Photomicrographs illustrating petrographic characteristics of Unit III grainstones. A. Mollusk grainstone, with both primary pores (pp) and secondary pores (sp) after dissolved mollusk fragments outlined by micrite envelopes; fringing cement rim both primary and secondary pore space. Sample 536-14-1, 20-21 cm. B. Codiacean algal grainstone, with primary pores (pp), rim cement, and algal grains replaced by calcite surrounding micrite-replaced filaments. Sample 536-16-1, 56-57 cm. C. Mollusk grainstone, with calcite-replaced gastropod, primary (pp) and secondary (sp) pore space, and cement-rimmed, micrite envelope (me). Sample 536-14-1, 45-49 cm. D. Mollusk grainstone, with secondary pore space (sp) within dissolved gastropod shell and primary pores (pp) in shell cavity. Outline of shell preserved by micrite envelopes (me). Sample 536-14-1, 45-49 cm. 

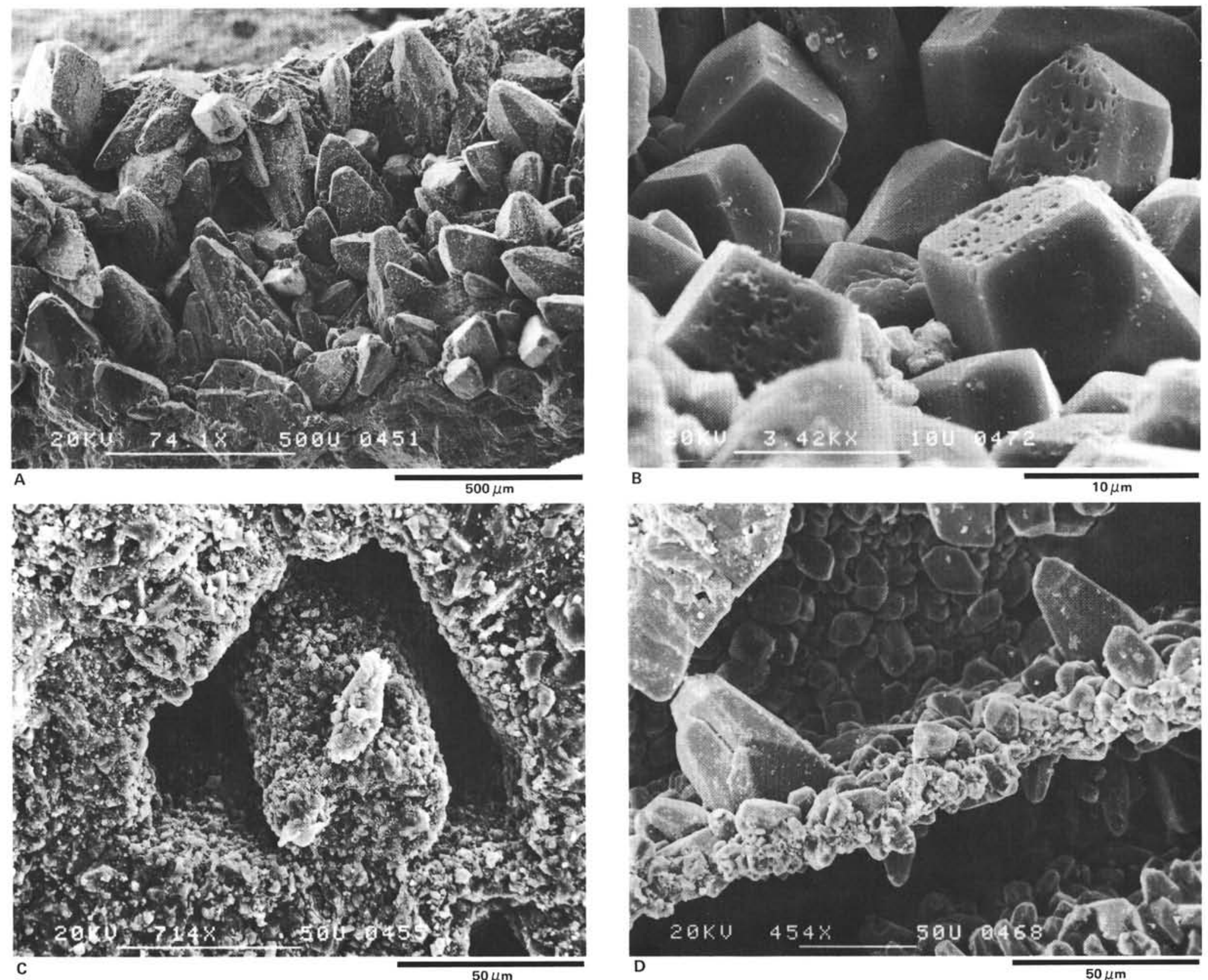

Figure 9. SEM micrographs. A. Calcite cement in coarse grainstone. Sample 536-11-1, 1-5 cm. B. Calcite cement with (solution?) pits in grainstone. Sample 536-18-1, 28-31 cm. C. Skeletal mold. Sample 536-11-1, 1-5 cm. D. Micrite rim with cement growing into both intra- and intergranular pore space. Sample 536-17-1, 4-8 cm. 
Submarine leaching driven by perched fresh water

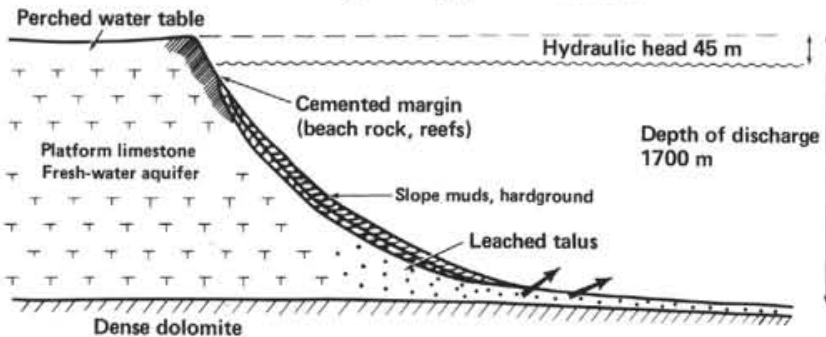

Figure 10. Possible scenario for freshwater leaching in platform talus. (See text for details.)

water aquifer. Although it has not been well documented in field situations, it appears probable from geochemical considerations that mixing-zone diagenesis could produce the fabrics observed in Site 536 talus deposits.

From the magnesium content of the whole rock, and published distribution coefficients (Winland, 1969; Benson and Matthews, 1971), the precipitating waters should have a $\mathrm{Mg} / \mathrm{Ca}$ ratio of about 0.375 . This ratio corresponds to a mixture of about 9 parts fresh water with a $\mathrm{Mg} / \mathrm{Ca}$ of about 0.05 (by weight) to 1 part seawater with $\mathrm{Mg} / \mathrm{Ca}$ of about 3. In following the same reasoning for strontium, the mixed water would be less than 1 part freshwater in 20 parts seawater. This approach does not produce agreement of the estimates of mixed waters in which alteration may have taken place, and the approach for strontium recently has been questioned by Land (1980).

Isotopic data again do not help us to identify the diagenetic environment for the reasons already mentioned, although the observed values could be produced in mixing zones.

Zonation in the cements revealed by cathodoluminescent petrography (Fig. 5) indicate fluctuating oxidation states or varying supplies of manganese and iron. Such fluctuations might be more easily achieved in a mixing zone than within a freshwater aquifer or a zone of buried seawater.

\section{SUMMARY}

Although freshwater diagenesis could account for the petrographic features of altered talus deposits at Site 536, it does not uniquely account for isotopic or trace-element characteristics. Also, the hydrologic setting required for freshwater alteration is not easily demonstrated for the Campeche Bank. A mixing-zone model does not account for the available trace-element data, but does require somewhat less drastic assumptions about the size of the freshwater lens. Although a seawater (bottom-water) alteration model requires no hydrologic difficulties, unusual circumstances are required to account for the geochemical characteristics of the talus deposits using this model. A more conclusive determination of the diagenetic milieu of Sites 536 talus deposits may come from detailed geochemical analyses of individual rock components.

\section{REFERENCES}

Allen, J. R., and Matthews, R. K., 1977. Carbon and oxygen isotopes as diagenetic and stratigraphic tools: Surface and subsurface data, Barbados, West Indies. Geology, 5:16-20.

Arthur, M. A., 1982. The carbon cycle-controls on atmospheric $\mathrm{CO}_{2}$ and climate in the geologic past. In Berger, W. H., and Crowell, J. C. (Eds.), Climate in Earth History: Washington (National Academic Press), pp. 55-67.

Back, W., and Hanshaw, B. B., 1970. Comparison of chemical hydrology of the carbonate peninsulas of Florida and Yucatan. $J$. Hydrol., 10:330-368.

Benson, L. V., and Matthews, R. K., 1971. Electron microprobe studies of magnesium distribution in carbonate cements and recrystallized skeletal grainstones from the Pleistocene of Barbados, West Indies. J. Sed. Petrol., 41:1018-1025.

Berger, W. H., 1979. Impact of deep-sea drilling on paleoceanography. In Talwani, M., Hay, W. W., and Ryan, W. B. F. (Eds.), Deep Drilling Results in the Atlantic Ocean: Washington (Am. Geophys. Union), Maurice Ewing Series, 3:297-314.

Bryant, W. R., Meyerhoff, A. A., Brown, N. K., Furrer, M. A., Pyle, T. E., and Antoine, J. W., 1969. Escarpments, reef trends, and diapiric structures, eastern Gulf of Mexico. Am. Assoc. Pet. Geol. Bull., 53:2506-2542.

Douglas, R. G., and Savin, S. M., 1975. Oxygen and carbon isotopic analyses of Tertiary and Cretaceous microfossils from Shatsky Rise and other sites in the Pacific Ocean. In Larson, R. L., Moberly, R., et al., Init. Repts. DSDP, 32: Washington (U.S. Govt. Printing Office), 509-520.

Enos, P., 1977a. Diagenesis of a giant: Poza Rica trend, Mexico. In Bebout, D. G., and Loucks, R. G. (Eds.), Cretaceous Carbonates of Texas and Mexico. Texas Bur. Econ. Geol., Rept., 89:324. , 1977b. Tamabra limestone of the Poza-Rica trend, Cretaceous, Mexico. In Cook, H. E., and Enos, P. (Eds.), Deep-Water Carbonate Environments. Soc. Econ. Paleontol. Mineral., Spec. Publ., 25:273-314.

Friedman, G. M., 1964. Early diagenesis and lithification in carbonate sediments. J. Sed. Petrol., 34(4):777-813.

Golubic, S., Perkins, R. D., and Lukas, K. J., 1975. Boring microorganisms and microborings in carbonate substrates. In Frey, R. W. (Ed.), The Study of Trace Fossils: New York (Springer-Verlag), pp. 229-259.

Hancock, J. M., and Kauffman, E. G., 1979. The great transgressions of the Late Cretaceous. J. Geol. Soc. London, 136:175-186.

Land, L. S., 1967. Diagenesis of skeletal carbonates. J. Sed. Petrol., 37:914-930.

1980. The isotope and trace element geochemistry of dolomite: The state of the art. In Zenger, D. H., Dunham, J. B., and Ethington, R. L. (Eds.), Concepts and Models of Dolomitization. Soc. Econ. Paleontol. Mineral., Spec. Publ., 28:87-110.

Lloyd, R. M., 1964. Variations in the oxygen and carbon isotope ratios of Florida Bay mollusks and their environmental significance. J. Geol., 72:84-111.

Manheim, F. T., 1967. Evidence for submarine discharge of water on the Atlantic continental slope of the southeastern United States, and suggestions for future search. N. Y. Acad. Sci. Trans., 29: 839-853.

Meyerhoff, A. A., 1980. Geology of Reforma-Campeche shefl. Oil \& Gas J., 78(16):121-124.

Plummer, L. N., 1975. Mixing of sea water with calcium carbonate ground water: Quantitative studies in the geological sciences. Geol. Soc. Am. Mem., 142:219-238.

Runnels, D. D., 1969. Diagenesis, chemical sediments, and the mixing of natural water. J. Sediment. Petrol., 39:1188-1201.

Schlager, W., Buffler, R. T., and Shipboard Scientific Party, 1984. DSDP Leg 77, Southeastern Gulf of Mexico. Geol. Soc. Am. Bull., 95:226-236.

Schlager, W., and James, N. P, 1978. Low magnesium calcite limestones forming at the deep-sea floor, Tongue of the Ocean, Bahamas. Sedimentology, 25:675-702.

Skirrow, G., 1975. The dissolved gases-carbon dioxide. In Riley, J. P., and Skirrow, G. (Eds.), Chemical Oceanography (2nd ed.): London (Academic Press), 2:1-192. 
Vail, P. R., Mitchum, R. M., and Thomson, S., III, 1977. Relative changes of sea level from coastal onlap. In Paxton, C. E. (Ed.), Seismic Stratigraphy-Applications to Hydrocarbon Exploration. Am. Assoc. Pet. Geol. Mem., 26:63-82.

Viniegra, O. F., 1981. Great carbonate bank of Yucatan, southern Mexico. J. Pet. Geol., 3:247-278.
Winland, H. D., 1969. Stability of calcium carbonate polymorphs in warm, shallow seawater. J. Sed. Petrol., 38:1579-1587.

Date of Initial Receipt: January 31, 1983

Date of Acceptance: July 22, 1983 